www.periodicos.unimontes.br/index.php/caminhosdahistoria

\title{
UM DEBATE SOBRE A ATUAÇÃO DO PARTIDO COMUNISTA BRASILEIRO (PCB) NO CAMPO ENTRE OS ANOS DE 1948 E 1964
}

\author{
Rafael Sandrin ${ }^{1}$
}

Recebido em: 17/04/2020

Aprovado em: 14/06/2020

Resumo: Este trabalho apresenta resultados parciais de uma pesquisa de mestrado sobre a atuação dos comunistas e do jornal "Terra Livre" junto aos camponeses entre os anos de 1948 e 1964. Com a entrada do PCB na clandestinidade em 1947, no governo do presidente Eurico Gaspar Dutra, o partido passou a privilegiar as ações armadas como forma de conquista do poder. Neste sentido, o uso de documentos históricos sobre a atuação dos comunistas no campo, como o Manifesto de Janeiro de 1948 e o Manifesto de Agosto de 1950 escritos pelo secretário do partido Luiz Carlos Prestes são fontes importantes para compreender o comportamento adotado pelo partido no meio rural. O jornal atuou de forma intensa a partir do ano de 1954, período em que apoiou a luta pela Reforma Agrária e a sindicalização dos camponeses, sem deixar de lado as lutas dos posseiros contra a expulsão que eram submetidos. Nesta perspectiva, as matérias dos exemplares do jornal são documentos que permitem destacar que o objetivo da direção pecebista era o de estimular os lavradores a lutarem pelos direitos sociais que eram desrespeitados como salário-mínimo e $13^{\circ}$ salário. A partir da declaração de 1958, o debate foi direcionado a respeito da garantia de tais benefícios destacados anteriormente, sendo que os comunistas abandonaram a perspectiva de revolução no campo. As manchetes do periódico são documentos complementares que permitem compreender o papel da imprensa em divulgar as estratégias de ação campo por parte dos dirigentes partido.

Palavras-chave: "Terra Livre", Camponeses, Trabalhadores Rurais, Partido Comunista, Comunistas.

\section{DEBATE SOBRE EL DESEMPEÑO DEL PARTIDO COMUNISTA BRASILEÑO (PCB) EN EL CAMPO ENTRE 1948 Y 1964}

Resumen: Este trabajo presenta resultados parciales de una investigación de maestría sobre el desempeño de los comunistas y el periódico "Terra Livre" con los campesinos entre los años de 1948 y 1964. Con la entrada del PCB escondido en 1947, bajo el gobierno del presidente Eurico Gaspar Dutra, el El partido comenzó a privilegiar las acciones armadas como una forma de conquistar el poder. En este sentido, el uso de documentos históricos sobre el desempeño de los comunistas en el campo, como el Manifiesto de enero de 1948 y el Manifiesto de agosto de 1950 escritos por el secretario del partido, Luiz Carlos Prestes, son fuentes importantes para comprender el comportamiento adoptado por el partido en el medio. rural. El periódico actuó intensamente desde 1954, cuando apoyó la lucha por la Reforma

\footnotetext{
${ }^{1}$ Mestre em História (PPH-UEM). Doutorando do Programa de Pós-Graduação em História. Universidade Estadual Paulista de Franca-SP, Brasil. E-mail: rafaelsandrin69@gmail.com. ORCID: https://orcid.org/00000002-6404-2483. Este artigo apresenta resultados de uma pesquisa de Mestrado desenvolvida junto ao Programa de Pós-Graduação em História da Universidade Estadual de Maringá (PPH-UEM), intitulada: “O Jornal "Terra Livre" e os trabalhadores rurais do Estado de São Paulo", defendida em 2013.
} 
Agraria y la sindicalización de los campesinos, sin descuidar las luchas de los ocupantes ilegales contra la expulsión a la que fueron sometidos. En esta perspectiva, los artículos en las copias de los periódicos son documentos que permiten resaltar que el objetivo del liderazgo pecebista era alentar a los agricultores a luchar por los derechos sociales que no fueron respetados como salarios mínimos y $13^{\circ}$ salarios. A partir de la declaración de 1958, el debate se orientó a garantizar tales beneficios previamente destacados, con los comunistas abandonando la perspectiva de la revolución en el campo. Los titulares de la publicación son documentos complementarios que permiten comprender el papel de la prensa en la divulgación de las estrategias de acción de campo por parte de los líderes del partido.

Palabras clave: "Terra Livre", campesinos, trabajadores rurales, partido comunista, comunistas.

\title{
A DEBATE ON THE PERFORMANCE OF THE BRAZILIAN COMMUNIST PARTY (PCB) IN THE COUNTRYSIDE BETWEEN 1948 AND 1964
}

\begin{abstract}
This work presents partial results of a master's research on the performance of communists and the newspaper "Terra Livre" with the peasants between the years of 1948 and 1964. With the entry of the PCB in hiding in 1947, under the government of President Eurico Gaspar Dutra, the party started to privilege armed actions as a way of conquering power. In this sense, the use of historical documents on the performance of communists in the field, such as the January 1948 Manifesto and the August 1950 Manifesto written by party secretary Luiz Carlos Prestes are important sources for understanding the behavior adopted by the party in the middle rural. The newspaper acted intensely from 1954, when it supported the struggle for Agrarian Reform and the unionization of peasants, without neglecting the squatters' struggles against the expulsion they were subjected to. In this perspective, the articles in the newspaper copies are documents that make it possible to highlight that the objective of the Pecebist leadership was to encourage farmers to fight for social rights that were disrespected as minimum wage and 13th salary. As of the 1958 declaration, the debate was directed towards guaranteeing such benefits previously highlighted, with the communists abandoning the prospect of revolution in the countryside. The headlines of the periodical are complementary documents that allow to understand the role of the press in divulging the strategies of action field by the party leaders.
\end{abstract}

Keywords: "Terra Livre”, Peasants, Rural Workers, Communist Party, Communists.

\section{Introdução}

Este trabalho tem o interesse em estudar as posições políticas dos comunistas no campo entre os anos de 1948 e 1964. O Partido Comunista Brasileiro (PCB) passou a ter liberdade de organização política com a democratização do país em 1945. No período do pósguerra, o partido buscou divulgar suas propostas no meio rural. A militância partidária atuou junto aos lavradores, que tinham seus direitos desrespeitados, como salário-mínimo e $13^{\circ}$ salário. Os comunistas atuaram na formação de Ligas Camponesas no interior paulista ${ }^{2}$. Tais

\footnotetext{
${ }^{2}$ As Ligas Camponesas de Santo Anastácio e de Lins são exemplos de associações civis constituídas por militantes pecebistas. Tais organizações foram fechadas pela "Polícia Política" no Estado de São Paulo (SILVA, 2003).
} 
associações civis incentivaram os camponeses a lutarem contra seus patrões. Porém, com a cassação dos direitos do partido, no Governo Dutra e com a entrada na ilegalidade ${ }^{3}$, muitas ligas foram fechadas pela polícia, pois as autoridades policiais consideraram tais entidades subversivas e sediciosas por serem dirigidas pelos adeptos do comunismo.

Diante do quadro de repressão aos comunistas e as lutas no campo, a direção pecebista passou a privilegiar a luta armada como estratégia para alcançar o poder. Tais posições estão expressas nos manifestos de janeiro de 1948 e no Manifesto de Agosto de 1950. Entretanto, o partido passou a pregar mudanças graduais de atuação do partido no campo com a declaração de março de 1958. Neste documento foi expressa uma maior ênfase dos militantes partidários na organização dos camponeses. Partindo desta premissa, num segundo momento de nossa discussão, iremos analisar o papel do jornal "Terra Livre" em estimular as lutas camponesas por meio de sindicatos rurais.

\section{A cassação do registro do PCB e as políticas para o campo}

Antes de estudarmos o posicionamento do PCB no que se refere a sua atuação no campo, cabe aqui desenvolver uma breve contextualização histórica. Conforme foi destacado pelo sociólogo Marcelo Ridenti (2000), o partido era considerado principal agremiação de esquerda antes no período anterior ao golpe que instituiu o Regime Militar em março de $1964^{5}$. Por ser uma importante força de esquerda o partido se tornou alvo principal do "Estado". Diante da conjuntura da Guerra Fria, o Governo Dutra "utilizou um dispositivo legal mediante o qual os "partidos antidemocráticos" poderiam ser impedidos de participação política" (SKIDMORE, 1982, p.93). Desta forma, o partido teve legalmente seus direitos cassados e passou a atuar na ilegalidade. A entrada na clandestinidade coincidiu com o início da luta ideológica entre Estados Unidos e União das Repúblicas Socialistas Soviéticas (URSS). O historiador Rodrigo Pato Sá Motta (2000), destacou que no imaginário brasileiro os comunistas eram considerados inimigos da nação, pessoas que praticavam males contra a

\footnotetext{
${ }^{3}$ Com base na decisão emitida pelo Tribunal Superior Eleitoral (TSE), o registro do PCB foi cassado no dia 7 de maio de 1947. Parlamentares eleitos tiveram seus mandatos cassados e as sedes do partido foram fechadas e invadidas pela polícia (SKIDMORE, 1982).

${ }^{4}$ O "Terra Livre" foi criado em 1949 com objetivo de orientar as Lutas Camponesas, visto que após a cassação dos direitos políticos do PCB em 1947 fez com que houvesse fechamento das Ligas Camponesas. TL, Nestor Vera. "O "Terra Livre" e as Lutas dos Camponeses". 5 de maio de 1949 a 5 de maio de 1963- Suplemento de Aniversário, p.3.

${ }^{5}$ Com o golpe Militar, o PCB deixou de ser principal força de esquerda devido a formação de grupos que se dedicaram a luta armada como forma de instituir socialismo. Sobre as lutas das esquerdas contra a Ditadura Militar ver: RIDENTI, 2010.
} 
sociedade e responsáveis por desestabilizar a ordem política. É importante considerar que o discurso anticomunista tinha espaço dentro da sociedade, visto que meios de comunicação mantinham posição contra a atuação dos socialistas no país.

O retorno à ilegalidade fez com que o Comitê Central elaborasse novas formas de o partido analisar a conjuntura política e formular políticas de organização social. A experiência marcada pela cassação dos direitos políticos fez com que a direção pecebista adotasse a Revolução Armada como estratégia de luta pela Reforma Agrária e pela melhoria das condições de vida dos camponeses. Desta forma, a mobilização dos lavradores sob a forma de associações civis foi abandonada.

Durante a reunião do Comitê Nacional do PCB em maio de 1948, Luiz Carlos Prestes apresentou informe de sua autoria e recorreu a Stálin para defender a tese de que seria necessária a constituição de uma Frente de Libertação Nacional. "Caberia a esta derrubar o Governo Dutra e instituir um regime democrático no país" (PRIORI, 2003, p.62). Tal frente congregaria estudantes, operários, profissionais liberais e a burguesia. Os burgueses eram considerados aliados na luta contra latifúndio e contra o imperialismo. Lênin interpretava a existência de grandes propriedades rurais como indício da existência de relações feudais na Rússia durante o período revolucionário ${ }^{6}$. Os comunistas entendiam que a existência de uma estrutura latifundiária no Brasil era um traço da dominação feudal, principalmente devido às relações de colonato e arrendamento.

O teórico Alberto Passos Guimarães interpretou que a existência de grandes propriedades rurais somada ao trabalho dos $\operatorname{colonos}^{7}$ e arrendatários caracterizava a prática de relações feudais no país. Já Caio Prado Jr contestava a ideia de que existia feudalismo no Brasil e acreditava que as relações de trabalho descritas acimas destacavam o avanço e a consolidação da exploração do capital. Portanto, o autor reforçou que era equivocada a premissa de que existiam relações de produção no campo de caráter feudal. Era corrente a interpretação dos comunistas de que a burguesia seria uma força produtiva que mostrava antagonismo a existência do latifúndio.

Os pecebistas destacavam que os lavradores eram explorados e submetidos a uma situação de miséria, principalmente parceiros, posseiros e arrendatários.

\footnotetext{
${ }^{6}$ Cf.: https://www.marxists.org/portugues/lenin/1917/05/13. Acesso em 16/04/2020.

${ }^{7}$ Os colonos eram trabalhadores rurais que realizavam serviços nas fazendas de café e tinham que conceder metade da colheita aos patrões. Geralmente realizavam o cultivo de cerca de mil pés de cafeeiros. Para complementar a renda, estes trabalhadores realizavam serviços avulsos diários. Eram responsáveis por retirar ervas daninhas das plantas de café e tinham um terreno onde poderiam cultivar hortas ou até mesmo criar porcos. (STOLCKE, 1986).
} 


\begin{abstract}
A Estratégia do PCB, para sensibilizar os camponeses e trabalhadores rurais para as hostes do partido era principalmente, levantar reivindicações que fossem concatenadas com as necessidades de cada segmento da população camponesa. Reivindicações elementares como melhores condições de trabalho, melhores e maiores prazos nos contratos de arrendamento, abolição dos vales de barracões e armazéns, liberdade para vender os produtos, crédito barato, garantia de preços mínimos, habitação e o pagamento do salário-mínimo para os assalariados eram medidas que poderiam facilitar a organização dos camponeses conforme os interesses do partido (PRIORI, 2003, p.65).
\end{abstract}

A defesa de tais reivindicações por parte do PCB, não significou que os comunistas tenham deixado de lado, a luta pela posse da terra. Visto que a direção pecebista considerava o latifúndio aliado do imperialismo europeu. No manifesto de agosto de 1950, Luiz Carlos Prestes defendeu a tese de que o país estava sendo dominado por empresas estrangeiras, representantes do imperialismo Norte-Americano.

\begin{abstract}
A dominação estrangeira assume a cada dia em nossa terra aspectos mais violentos e sombrios. Marchamos no caminho da escravidão colonial e de perda total de nossa soberania. As posições chaves da economia de nosso país são dominadas pelos monopólios Norte-Americanos e, o comércio de nossos principais produtos de exportação estão sob o controle de firmas Norte-Americanas, a indústria nacional quando já não pertence aos monopólios ianques está sob a constante ameaça de aniquilamento e no próprio comércio interno avança o controle dos consórcios norte americanos (PRESTES, 1982, p.142).
\end{abstract}

Ainda de acordo com análise de Prestes (1982, p. 142), o imperialismo impossibilitava a emergência de um burguesia nacional produtiva. Moisés Vinhas considerou que a postura adotada pelo partido com o manifesto de agosto de 1950 era sectária, dogmática pelo fato de os comunistas terem se afastado dos sindicatos, locais em que atuavam junto às massas trabalhadoras. A direção pecebista considerou as entidades sindicais como organizações que estavam a serviço dos latifundiários, e do Estado. Neste sentido, os comunistas "procuraram então, constituir organizações puras e autônomas, consideradas revolucionárias. Nas empresas onde desfrutavam de influencia procuravam realizar greves" (VINHAS, 1980, p.129).

Vinhas considerou que a experiência da militância comunista mostrava que não era viável o rompimento com os sindicatos. Com entrada na ilegalidade, órgãos sindicais foram vistos pelos dirigentes do PCB como favoráveis aos patrões. "Os ativistas que faziam oposição em tais organizações eram estigmatizados e omissos no enfrentamento contra o Estado e adesista em relação ao modelo sindical vigente" (COSTA, 1995, p.149). Parte da militância comunista mantinha posição contrária à direção do partido, pois seus membros continuaram trabalhando em defesa dos trabalhadores em tais organizações devido a trajetória de luta em prol dos direitos da classe operária. 
Os dirigentes comunistas modificaram suas posições em relação aos comunistas que atuavam junto aos sindicatos. A resolução aprovada no mês de julho de 1952 estabeleceu o retorno dos militantes as atividades junto à organização dos operários. É importante deixar claro que devido a postura contrária aos líderes pecebistas, a militância exerceu pressão para convocar um amplo ativo sindical em 1952 (COSTA, 1995, p. 168). Os comunistas conquistaram êxito na direção de grandes atos de paralização das atividades. O PCB teve papel de destaque na realização da greve dos 300 mil, realizadas nos meses de março e abril de 1953: "Naquele contexto da década de 1950, houve perda do poder aquisitivo dos trabalhadores e o aumento do custo de vida, pois houve aumento dos produtos da cesta básica" (COSTA, 1995, p.168).

Houve manifestações grevistas de grandes proporções que tiveram início na cidade de São Paulo, ou seja, a greve dos 300 mil, na fábrica de tecidos Matarazzo no Bairro do Belenzinho. Os atos de paralisação das atividades contavam com a presença maciça de operários paulistanos que reivindicavam estabilidade no emprego, aumento de 60 por cento no salário e adoção de medidas contra carestia. Enquanto a direção estava preocupada em derrubar o regime de Vargas, os militantes defendiam a organização dos trabalhadores por meio dos sindicatos (VINHAS, 1982, p. 132).

A estratégia que pregava a revolução armada como forma de alcançar o poder não foi abandonada. Partindo deste pressuposto, quadros do PCB foram deslocados para áreas de conflitos como o de Trombas e Formoso no Estado de Goiás e em Porecatu na região Norte do Estado do Paraná, tendo em vista incentivar os camponeses a realizarem revolução comunista.

A Revolução seria obra do partido, que através de um grupo de iluminados,
do herói positivo e das massas passivas, tomaria o poder e implantaria o
socialismo do dia para noite. Em qualquer lugar onde surgisse uma luta, essa
poderia ser o foco de uma revolução vitoriosa. E nós levávamos isso a
pratica isso a serio. Quando surgiu uma luta camponesa em Porecatu, que era
uma luta de massa, uma luta de posseiros, uma luta correta, nós nos metemos
nela com objetivo de transforma-la na centelha que iria incendiar o campo
brasileiro, dar inicio a revolução agrária. Fracassamos (DEL PICHIA, 1980,
p.23).

O partido passou a reproduzir na Revolta de Porecatu e de Trombas e Formoso a estratégia utilizada na Revolução Chinesa em que a cidade foi cercada pelo campo. "Os comunistas se lançaram na Revolta de Porecatu e de Trombas e Formoso, devido a influência 
da experiência da revolução chinesa de Mao Tse Tung, que conquistou o poder em 1949"8 (PRIORI, 2003, p.71).

Os pontos aprovados no IV congresso chamaram a atenção para realização de uma Reforma Agrária, com o confisco das terras dos latifundiários e a distribuição de pequenas propriedades rurais aos camponeses pobres. O regime da pequena propriedade foi considerado pelos pecebistas como fundamental para o desenvolvimento do país. Durante a realização do congresso, Oto Santos (Calil Chade) apresentou informe de sua autoria, onde destacou que o PCB teve importantes experiências nas lutas dos trabalhadores rurais de Porecatu, Santo Anastácio e Canápolis (SANTOS, 1955). O autor defendeu a tese de que a direção do partido deveria apoiar a formação dos sindicatos de trabalhadores rurais.

Com a realização da $1^{a}$ CNTA em 1953 e da $2^{a}$ CNTA em 1954 houve a criação da União dos Lavradores e Trabalhadores Agrícolas (ULTAB). Por meio desta entidade, o PCB passou apoiar a formação dos sindicatos de camponeses, para incentivar os homens do campo a lutarem pelos seus direitos. O incentivo a sindicalização, não significou que a direção pecebista tenha abandonado os rumos políticos adotados após a entrada na ilegalidade, visto que o partido ampliou as formas de atuação política junto aos trabalhadores rurais.

Essa organização vai reforçar as atividades do PCB no campo e ampliar as atividades do PCB no campo e ampliar o leque de atuação, flexibilizando as lutas camponesas. Evidentemente que a tese da luta armada não será deixada de lado, Trombas e Formoso são exemplos mais concretos sobre isso, - mas a ênfase será dada para outras possibilidades (PRIORI, 2003, p.78).

$\mathrm{Na}$ tarefa de estimular a organização dos trabalhadores rurais, os comunistas contaram com apoio do Jornal "Terra Livre". Nesta perspectiva, o periódico passou a realizar a propaganda de associações que defendiam os interesses dos homens do campo. As matérias jornalísticas destacaram de forma reiterada que os camponeses deveriam constituir sindicatos para lutar pelo direito ao salário-mínimo e férias remuneradas 9 .

Por meio do "Terra Livre" a direção pecebista incentivou a criação de entidades sindicais no campo nos municípios do interior do Estado de São Paulo. Tais organizações procuravam mobilizar os camponeses para realização de uma aliança operário-camponesa,

\footnotetext{
${ }^{8}$ A Revolta de Porecatu teve início na década de 1950 na região de Porecatu, localizada no Norte do Estado do Paraná. No entanto é importante destacar que o partido enviou militantes treinados, armamentos munições, roupas e alimentos. Ao estudar o conflito de Porecatu o historiador Ângelo Priori destacou que o PCB foi o principal mentor da resistência armada por meio do diretório municipal de Jaguapeba e do Diretório estadual. A região de Porecatu foi ocupada por arrendatários e empregados da fazenda de café da região da Sorocabana. Grileiros reivindicaram a posse da terra e contaram com apoio da polícia e de jagunços armados para expulsar os posseiros. Cf.: PRIORI, 2011.

${ }^{9}$ A criação e o fortalecimento dos Sindicatos Rurais. O caminho para vitória. TL, Ano VII, $1{ }^{\text {a }}$ Quinzena de Julho de $1956, \mathrm{~N}^{\circ} 67$.
} 
visando a realização da Revolução Democrático-Burguesa. O periódico destacou que a formação de associações de campesinos no interior do Estado de São Paulo contava sempre com a participação de uma liderança camponesa ${ }^{10}$.

As associações de camponeses e o "Terra Livre" incentivaram os lavradores a entrarem na Justiça contra seus patrões, pois os direitos como férias e salário-mínimo eram desrespeitados. Tais entidades diferiam dos sindicatos, visto que não necessitavam do reconhecimento do Ministério Público, apenas necessitavam do registro em cartório.

Efetivamente até fins dos anos 1950, havia apenas cinco sindicatos reconhecidos na área rural do país, o que era atribuído em encontros de trabalhadores, as dificuldades interpostas pelo Ministério do Trabalho visando dificultar a criação e o funcionamento destas entidades (GRYNSPAN; DEZEMONE, 2007, 221).

Por meio da ULTAB e do jornal a direção do partido incentivou a formação de associações, pois o Ministério do Trabalho dificultou a criação dos sindicatos, visto que as elites agrárias eram contrárias a organização dos camponeses.

A declaração de março, aprovada em 1958 destaca que o partido modificou seu comportamento em relação a atuação no campo. Portanto, PCB e o "Terra Livre" voltaram suas ações para a luta de redução das taxas dos aluguéis, e pelo direito dos trabalhadores rurais. Assim, o partido abandonou a estratégia de luta armada e da violência revolucionária adotada com os manifestos de 1948 e 1950, consolidada no IV congresso em 1954. Apesar de a militância comunista ter direcionado seus esforços na sindicalização dos campesinos, haviam dificuldades na tarefa de mobilizar os lavradores na luta por seus direitos, visto que a quantia de associações civis era pequena ${ }^{11}$.

Durante a realização da primeira conferência da ULTAB a organização dos camponeses sob a forma de associações foi tema principal das discussões. O documento aprovado durante esta reunião nos mostra as dificuldades concernentes a sindicalização dos lavradores. Segundo a resolução aprovada, o isolamento dos trabalhadores rurais que viviam em regiões distantes e a perseguição e negação de direitos por parte dos patrões eram fatores

\footnotetext{
${ }^{10}$ Era comum a participação de Nestor Veras na fundação de entidades sindicais. O referido líder camponês era colaborador do Jornal "Terra Livre”, e membro do núcleo responsável pela atuação do PCB no campo junto com Lindolfo Silva. O militante percorria cidades paulistas incentivando a formação de sindicatos de trabalhadores rurais, portanto era destacada de forma veemente sua presença na formação de entidades sindicais. Em uma reunião realizada no dia 4 de janeiro de 1956, foi fundada a Associação dos lavradores e trabalhadores agrícolas de Flórida Paulista. No mês de outubro esta entidade foi registrada no cartório da Comarca de Pacaembu. Foi destacado no jornal que os trabalhadores de Dracena fundaram comitês constituídos por trabalhadores rurais e posteriormente haviam fundado a União dos trabalhadores agrícolas de Dracena. TL, Ano VII, Abril de 1956, N 64, p.3.

${ }^{11}$ Relatório sobre a organização dos lavradores e trabalhadores rurais. TL, Ano XI Fevereiro de 1960, Nº 88, p.3.
} 
que impediam a organização política no campo $^{12}$. Além de não respeitar os direitos, os fazendeiros utilizavam a repressão policial e jagunços contra os lavradores que participavam de atividades sindicais e greves no interior paulista.

Foi ressaltado durante a reunião que o operariado urbano poderia ajudar e orientar os lavradores na fundação de órgãos sindicais. A direção do partido acreditava que os operários eram importantes na mobilização dos camponeses e que já possuíam tradição na organização das massas trabalhadoras. As publicações do "Terra Livre" dão ênfase a formação e a atuação de lideranças de sindicatos na luta pelos direitos dos homens do campo, principalmente no Estado de São Paulo, área em que havia grande quantia de pessoas que trabalhavam na cafeicultura.

O periódico foi responsável pela divulgação de eventos, ou seja, conferências voltadas aqueles que trabalhavam em áreas rurais. A $2^{\text {a }}$ Conferência Nacional dos Trabalhadores Rurais realizada em São Paulo em 1954 fazia parte da estratégia do PCB que privilegiava a distribuição das terras aos camponeses que não possuíam propriedade para trabalharem. Muitos posseiros estavam sendo expulsos dos locais em que cultivavam. A luta pela posse da terra foi premissa defendida pela direção pecebista. Eventos como este que foi mencionado podem ser pensados como momentos que expressavam dos lavradores o interesse em lutar pela melhoria das condições de vida independentemente de serem de pequeno, médio ou grande porte.

O jornal se esforçou no sentido de estimular as massas camponesas a participarem dos eventos envolvendo trabalhadores rurais. É necessário enfatizar que as reuniões envolvendo campesinos eram divulgadas para constituir quadros do partido em áreas rurais. Deste modo, o PCB buscou aumentar o quadro de militantes no campo.

A $2^{\text {a }}$ Conferência Nacional de Lavradores e Trabalhadores Rurais do Estado de São Paulo, $2^{\text {a }}$ CNTA, realizada na cidade de São Paulo em 1954 foi considerada um dos principais eventos realizados sobre a égide do partido. O jornal procurou defender a tese de que os participantes do evento exigiram do "Estado" a distribuição de terras aos posseiros. Os jornalistas do "Terra Livre" destacaram que os lavradores estavam interessados em participar da $2^{\text {a }}$ CNTA. O corpo editorial procurava legitimar a tese de que os camponeses estavam despertando consciência de classe e preocupados com a distribuição de terras.

O corpo editorial destacava que os eventos eram espaços destinados a discussões sobre problemas que ocorriam no campo e espaços de socialização de experiências políticas

\footnotetext{
${ }^{12}$ Relatório sobre a organização dos lavradores e trabalhadores rurais. TL, Ano XI Fevereiro de 1960, № 88, p.3.
} 
de lutas. A presença dos lavradores em eventos foi representada pelo jornal como indícios de que as massas trabalhadoras rurais estavam mantendo posição contrária aos patrões e a favor da distribuição das terras aos camponeses.

Por ser jornal responsável pela divulgação das ideias do PCB, o "Terra Livre" promoveu um debate sobre a Reforma Agrária. A realização da $2^{\mathrm{a}}$ Conferencia Nacional de Trabalhadores Agrícolas em 1954, resultou na constituição da União dos Lavradores e Trabalhadores Agrícolas do Brasil (ULTAB), entidade que se tornou braço de apoio do da direção pecebista na organização e sindicalização dos trabalhadores agrícolas. "Cabe aqui destacar que neste evento houve a participação de "272 lavradores, 20 delegados representantes de sindicatos operário, e 11 urbanos" (COSTA, 1996, p.28-29). Nesta assembleia foi manifestada preocupação na realização da Reforma Agrária. A luta pela distribuição das terras aos camponeses não foi deixada de lado, mesmo diante do interesse do partido em apoiar a organização sob a forma de associações.

A luta pelo fim do latifúndio foi manifestada em um documento aprovado durante a realização da $2^{\mathrm{a}}$ conferencia de lavradores, intitulado "Carta dos Direitos e das Reivindicações dos Trabalhadores Agrícolas do Brasil" ${ }^{\prime 13}$. Neste escrito foi concedido destaque a luta dos camponeses de diversas categorias como posseiros e assalariados e trabalhadores da lavoura cafeeira e canavieira. A concessão de terras aos camponeses foi considerada pelos comunistas medida importante para que mudassem as condições de vida do homem do campo. Portanto houve então um aprofundamento do debate sobre desestruturação das grandes propriedades rurais neste encontro.

A preocupação e interesse na distribuição de terras foi manifestada durante a realização de uma reunião presidida no dia 17 de dezembro de 1954 pelo presidente da ULTAB José Tibúrcio e divulgada pelo "Terra Livre”. O jornal procurou chamar atenção de seus leitores de que durante a realização do evento, os participantes direcionaram seus esforços na realização da reforma agrária. O latifúndio foi considerado pelo periódico como fator que contribuía para o empobrecimento dos lavradores. Na mesma reunião a comissão executiva da ULTAB aprovou o memorial da Campanha Nacional da Reforma Agrária, cujo objetivo era adquirir cinco milhões de assinaturas em prol da concessão de terras aos lavradores brasileiros ${ }^{14}$.

\footnotetext{
${ }^{13}$ Carta dos Direitos e das Reivindicações dos Lavradores e Trabalhadores Agrícolas do Brasil foi publicada na edição. TL, Ano V, $2^{\text {a }}$ Quinzena de setembro, $1^{\text {a }}$ Quinzena de Outubro de 1954, No 49 , p.4.

${ }^{14}$ A campanha nacional da Reforma Agrária foi lançada no Teatro Colombo, numa reunião realizada no dia 17 de dezembro de 1954. A campanha pela Reforma Agrária. Ampla união de forças pelo progresso do Brasil. TL, São Paulo, $1^{\text {a }}$ Quinzena de março de $1955, N^{\circ} 53$. No 62 , p.1.
} 
Pelos termos usados no memorial, buscava-se falar não só para os trabalhadores do campo, mas para a sociedade, no momento em que se enfatizava o desenvolvimento do mercado interno e mostravam a relação entre a reforma agrária e o progresso da economia mundial. $\mathrm{O}$ evento foi lançado em São Paulo, no teatro Colombo, com apoio de dois senadores, três generais, 81 deputados federais, dezenas de deputados estaduais, secretários de Estado, juízes, promotores públicos, prefeitos, jornalistas e outras personalidades (CASTANHO, 2009, p.92).

É importante destacar que a participação de políticos foi descrita pelo periódico como indício de que a existência de propriedades de pequeno e de médio porte era importante para sociedade. O corpo editorial procurou defender a tese de que vários setores sociais demonstraram em participar da Campanha Nacional pela Reforma Agrária. O "Terra Livre" orientou os lavradores para que organizassem comissões nas fazendas para arrecadarem assinaturas, visando doação de terras aos camponeses. No início da campanha, os redatores do periódico destacaram que a quantia de assinaturas arrecadadas ainda era pequena.

A coluna "Reformas Agrárias de todo mundo" 15 foi introduzida no jornal com objetivo de estimular a desestruturação dos latifúndios. O periódico procurou divulgar as experiências que consistiram na distribuição de terras aos camponeses sem terra ou com pouca terra para trabalhar em outros países. Esta seção destacou que os projetos de concessão de lotes aos lavradores na China, Rússia contribuíram para a melhoria das condições de vida da população.

Os jornalistas consideravam que a concessão de terras aos camponeses por si mesma não melhoria as condições de vida do povo brasileiro. Os membros do corpo editorial destacavam nas reportagens e procuravam chamar a atenção de seus leitores, de que os lavradores deveriam lutar por medidas que regulamentassem regime de arrendamentos, acesso a crédito em longo prazo aos lavradores. Na visão dos comunistas, não bastava apenas dar terras aos despossuídos, mas oferecer empréstimos para o desenvolvimento de atividades agrícolas.

O "Terra Livre" destacou que autoridades como prefeitos, vereadores e até deputados participavam de eventos em prol da distribuição das terras aos campesinos. O periódico buscou defender a tese de que no interior do Estado de São Paulo, os lavradores manifestaram adesão ao projeto de fim dos latifúndios. Nesta perspectiva, o jornal divulgou um evento realizado na cidade de Marília, no dia 5 de fevereiro de 1955, que não contou apenas com a

15 “A Coluna Reformas Agrárias de todo o Mundo", passou a ter espaço no "Terra Livre" a partir do exemplar TL, Ano, VII, São Paulo, $1^{\mathrm{a}}$ Quinzena de janeiro de 1955, Nº 52, p.3. 
participação de camponeses dos municípios de Marília, mas com lavradores dos municípios de Garça, Pompéia e Vera Cruz ${ }^{16}$.

O comparecimento de duas mil pessoas no município de Marília foi interpretado pelos jornalistas como exemplo de que a sociedade demonstrou interesse em participar da Campanha Nacional da Reforma Agrária. Nesta perspectiva, os redatores destacaram que não foram apenas os lavradores que lutaram pelo fim dos latifúndios ${ }^{17}$.Desta forma, os comunistas que trabalhavam como jornalistas esperavam conseguir a adesão dos camponeses as ideias pecebistas.

Os operários foram considerados como agentes sociais importantes na luta pela distribuição de terras aos camponeses, por terem ajudado os lavradores a recolherem assinaturas no meio rural e urbano $^{18}$. Na análise do periódico, o operariado se mantinha em defesa dos camponeses. O jornal fez um balanço da coleta de assinaturas e divulgou a quantia de 66.723 adesões para a campanha em prol do fim do latifúndio, sendo que o estado de São Paulo adquiriu 38.000 até o mês de julho de 1954.

A grande concentração de terras nas mãos de poucos proprietários foi considerada pelo "Terra Livre" como causa do atraso no campo.

Na verdade, na visão que se afirmou o atraso no campo, em decorrência do
latifúndio, operava como uma ancora que impedia o desenvolvimento do
país, tornando-o vulnerável aos interesses imperialistas. Segundo análises
que se tornaram correntes, isso ocorria, porque, relegando a pobreza e ao
isolamento, as populações rurais que até a década de 1950 representavam
cerca de 70 por cento da população do país, o latifúndio impedia o
alargamento do mercado interno e o processo de industrialização
(GRYNSPAN; DEZEMONE, 2007, p.217).

$\mathrm{Na}$ avaliação do periódico, a queda da produção agrícola e a fome do povo brasileiro seriam extintas por meio da distribuição de terras aos camponeses. Este argumento foi utilizado pelos jornalistas para mobilizar os lavradores a assinarem o memorial. O corpo editorial procurava chamar a atenção de seus leitores, que segundo os dados estatísticos divulgados pelo Serviço Nacional de Recenseamento, entre os anos de 1940 e 1950 houve diminuição das pequenas propriedades rurais que de 252.615 passaram para 221.609 em todos estados brasileiros ${ }^{19}$.

\footnotetext{
${ }^{16}$ Comício de Marília, um exemplo para o Brasil. Ano VIII. São Paulo, $2^{\mathrm{a}}$ Quinzena de março de $1955, \mathrm{~N}^{\circ} 54$, p. 4 .

${ }^{17}$ Comício de Marília, um exemplo para o Brasil. Ano VIII. São Paulo, $2^{\mathrm{a}}$ Quinzena de março de 1955, № 54, p.4.

${ }^{18}$ Participarão os operários da coleta de assinaturas pela Reforma Agrária. TL, Ano VII, $1^{a}$ Quinzena de Fevereiro de $1956, \mathrm{~N}^{\circ} 51, \mathrm{p} .2$.

${ }^{19}$ Avança o latifúndio. Desaparecem os patrimônios. TL, Ano V, São Paulo, $1^{\text {a }}$ Quinzena de agosto de 1954, No 46, p.1.
} 
Trata se de uma tarefa difícil mensurar a quantia de adesões ao projeto que previa o fim das grandes propriedades rurais, pois o jornal não havia divulgado esta informação. Entretanto, a luta pela distribuição de terras teve novos desdobramentos. Neste sentido foi realizada a Primeira Conferência da ULTAB na capital paulista entre os dias 18 e 20 de setembro de 1959, que resultou na aprovação de um texto intitulado "Carta sobre a Reforma Agrária”20. Apesar de a reunião ter resultado na aprovação do documento, as estratégias dos comunistas foram voltadas à organização dos lavradores e trabalhadores rurais por meio da formação de uma ampla rede sindical.

Se por um lado os comunistas atuavam em defesa dos trabalhadores assalariados por meio de associações, por outro lado, não deixaram de considerar importante a luta pela posse da terra, visto que havia muitos camponeses que eram expulsos das terras em que trabalhavam. Portanto, a ULTAB era uma entidade do PCB que buscou atuar em todas as frentes. Temos que destacar que "Este documento reproduzia os elementos básicos contidos na declaração e março, aprovada pelo Comitê Central no ano anterior" (FALEIROS, 1989, p.224).

Segundo a avaliação dos comunistas, a reforma agrária isolada não iria melhorar as condições de vida dos lavradores.

\begin{abstract}
Não basta naturalmente que cada agricultor que cada agricultor possua um lote como propriedade. O objetivo da Reforma Agrária é o aumento da produção em beneficio da maioria do povo. A Reforma Agrária, é o aumento da produção em beneficio da maioria do povo. A Reforma Agrária compreende, por isso, uma grande série de outras providências, tais coo a organização da assistência do Estado em vários terrenos: agro técnica, crédito, educação, saúde, cooperativismo e outros ${ }^{21}$.
\end{abstract}

Foi destacado pelo "Terra Livre" que caberia ao Estado facilitar a compra de instrumentos agrícolas modernos, de adubos, inseticidas e estimular o cooperativismo entre os trabalhadores agrícolas. O periódico trabalhou na conscientização de seus leitores para que estes exigissem do governo, não somente a Reforma Agrária, mas a aplicação de tais medidas mencionadas anteriormente ${ }^{22}$.

Os jornalistas defenderam a tese de que os trabalhadores participantes da conferência estadual exigiram das autoridades políticas, a desapropriação de áreas rurais, pagamentos de indenizações, e aplicações de medidas graduais no campo, como financiamento a longo prazo direito a sindicalização e assistência técnica. Tais medidas estavam expressas na declaração

\footnotetext{
${ }^{20}$ Carta sobre a Reforma Agrária. TL, Ano XI, No 87, Janeiro de 1960, p.10.

${ }^{21}$ Carta sobre a Reforma Agrária. TL, Ano XI, No 87, janeiro de 1960, p.10.

${ }^{22}$ Carta sobre a Reforma Agrária. TL, Ano XI, No 87, janeiro de 1960, p.10.
} 
de março de 1958. Por meio deste documento, o partido comunista destacou que as medidas citadas acima iriam contribuir com o desenvolvimento do país. O PCB deixou de lado a realização de uma revolução armada, em detrimento de políticas que promovessem a conquistas de direitos que eram desrespeitados pelos patrões como salário-mínimo por exemplo. É necessário destacar que o período em que os comunistas voltaram suas atuações junto aos sindicatos foi marcado por um processo de desestalinização do partido comunista, que realizou uma crítica as suas formas de atuação no campo. Com a divulgação dos crimes praticados por Stálin por Kruschev em 1956, a direção pecebista abandonou a estratégia de tomada de poder por meio de uma Revolução e da luta armada.

A Conferência Nacional da ULTAB foi evento preparatório para a realização do $1^{\circ}$ Congresso Nacional de Trabalhadores Rurais de Belo Horizonte realizado entre os dias 15, 16 e 17 de novembro de 1961 em Belo Horizonte, ocasião em que os lavradores exigiram do "Estado" eliminação do latifúndio, distribuição de terras aos camponeses. Cabe aqui ressaltar que a Reforma Agrária foi considerada o centro dos debates. E necessário reiterar que o evento em Belo Horizonte foi a primeira reunião de trabalhadores rurais a nível nacional, que foi organizada pela ULTAB.

O periódico enfatizou reiteradamente para os lavradores organizarem comissões nas fazendas para elegerem delegados para representá-los no congresso. Visto que todos os trabalhadores não tinham condições de participar das tomadas de decisões. Além disso, o jornal divulgou o documento aprovado durante a realização do referido evento. No que concerne a estrutura agrária brasileira foram aprovados os seguintes pontos:

(A) A transformação da atual estrutura agrária do país, com o monopólio da grande propriedade da terra exercido pelos latifundiários, principalmente com a desapropriação do Governo Federal, dos latifúndios, substituindo-se a propriedade monopolista da terra pela propriedade camponesa, em forma individual ou estatal;

(B) Máximo acesso a posse e ao uso da terra pelos que desejam trabalhar a base da venda, do usufruto ou aluguel a preços módicos das terras desapropriadas aos latifúndios e da distribuição gratuita das terras devolutas ${ }^{23}$.

Apesar de a conferência ter sido organizada pela ULTAB, contou com participação de outros movimentos sociais que atuavam no campo, como as Ligas Camponesas e os Movimentos dos agricultores sem terra (MASTER). O “Terra Livre" destacou que o evento foi espaço democrático, voltado a decisões políticas. No congresso, o líder camponês

\footnotetext{
${ }^{23} 1.800$ delegados exigiram em Belo Horizonte a realização da Reforma Agrária. TL, São Paulo, Ano VIII, No 105, Novembro de 1961, p.1.
} 
Francisco Julião que era expoente das Ligas Camponesas, defendeu a tese de que deveria ser realizada uma Reforma Agrária Radical. O congresso expressou a luta entre as Ligas e os comunistas pela representação do campesinato.

O congresso de Belo Horizonte explicitou assim, uma intensa disputa pela representação do campesinato, que se desenvolvia envolvendo o PCB e as Ligas Camponesas de Pernambuco, lideradas por Francisco Julião. Como mencionado acima, discutia-se o próprio sentido de que ser "radical" e sua vinculação com o processo revolucionário no Brasil. Num contexto de efervescência política, o que passava a contar eram as ações e seus efeitos políticos e a elas a imprensa passou a dar maior destaque (MEDEIROS, 1995, p.116).

Não havia um consenso sobre a forma como iria se dar a distribuição das terras aos camponeses. Os membros da ULTAB acreditavam que a Reforma Agrária deveria ser feita de forma lenta e gradual por meio da luta pela diminuição das taxas de arrendamento e melhoria das condições de vida dos trabalhadores rurais. Os comunistas entendiam que a legislação trabalhista deveria ser estendida aos lavradores, como direito a férias, $13^{\circ}$ salário, saláriomínimo. Portanto, a estratégia adotada com a declaração de 1958 foi corroborada no presente congresso.

\section{Considerações finais}

Por meio dos manifestos de janeiro de 1948 e agosto de 1950, o partido comunista adotou postura que pregava a violência revolucionária como forma de alcançar o poder e realizar a Revolução Agrária. As experiências de atuação no campo na Revolta de Porecatu no Norte do Paraná e em Trombas e Formoso em Goiás foram concebidas pelo partido como forma de tomar o poder e derrubar o governo do presidente Dutra.

Como podemos perceber ao longo desta discussão o jornal passou a privilegiar a realização da Reforma Agrária como forma de luta política em detrimento da organização dos trabalhadores rurais, muito embora a postura adotada pelo partido fosse questionada pela militância que pregava o retorno aos sindicatos e atuação nas greves.

As notícias do "Terra Livre" foram importantes documentos que possibilitaram compreender as mudanças políticas gradativas que o PCB passou. A realização da $2^{\mathrm{a}}$ CNTA, iniciou um período de ruptura com a linha adotada após cassação dos direitos políticos, mas como vimos isso não significou que os comunistas abandonassem a estratégia adotada com os manifestos de janeiro e de agosto. A realização da referida conferencia concede a dimensão de que o partido passou a apoiar a organização dos trabalhadores rurais. 
Com a aprovação da declaração de março de 1958, a direção do PCB passou a estimular a organização dos camponeses e a formação de associações de trabalhadores rurais. Esta estratégia adotada pelo partido é demonstrada nas matérias do "Terra Livre", visto que o jornal intensificou apoio a formação dos sindicatos.

\section{Fontes}

\section{Jornal "Terra Livre" (1954-1964)}

Lénin, V.I. Relatório sobre a Questão Agrária. Primeira. edição: Publicado pela primeira vez em 1921 nas Obras de N. Lenine (V. Uliánov), tomo XIV, parte II . Fonte: Obras Escolhidas em Três Tomos,1977, tomo 2, pág: 82 a 85. Edições Avante! - Lisboa, Edições ProgressoMoscovo. Tradução Edições" Avante!" com base nas Obras Completas de V. I. Lénine, 5. a ed. Em russo, t. 31, pp. 416-421. Transcrição e 2347. Direito e Práxis, Rio de Janeiro, Vol. 08, N.3, 2017, p. 2314-2349. Ana Claudia Diogo Tavares e Mariana Trotta Quinta ISSN: 21798966HTML: $\quad$ https://www.marxists.org/portugues/lenin/1917/05/13. Acesso em 16/04/2020.

SANTOS, O. O Programa do Partido, a Questão Agrária, a organização e as lutas dos camponeses. Intervenção do IV Congresso do Partido Comunista Brasileiro. Novembro de 1954. In: Problemas. Revista Mensal de Cultura Política, nº4, dezembro de 1954 a fevereiro de 1955.

\section{Referências bibliográficas}

CASTANHO, S.M. A ação do PCB, da ULTAB e do jornal "“Terra Livre"” na luta pela Reforma Agrária. In: CASTANHO, S.M. Lei, trabalho e política no Brasil. Maringá: Eduem, 2009.

COSTA, L.F.C O sindicalismo rural brasileiro em construção. Rio de Janeiro: Forense Universitária, 1996.

COSTA, H.da. Em busca da memória: Comissão de Fábrica, Partido e sindicato no pósguerra. $1^{\text {a }}$ Ed. São Paulo, Página Aberta, 1995.

FALEIROS, I. Percursos e Percalços no campo (1922-1964). Tese (Doutorado) - Programa de Pós-Graduação em Sociologia, Universidade de São Paulo, São Paulo, 1989.

GRYNSPAN; DEZEMONE. As Esquerdas e a descoberta do campo brasileiro: Ligas Camponesas, comunistas e católicos (1950-1964). In: FERREIRA, J; REIS, D. Nacionalismo e Reformismo Radical (1945-1954). Rio de Janeiro: Civilização brasileira, 2007.

GUIMARÃES, A.P. Quatro Séculos de Latifúndio. In: STÉDILE, J.P. A Questão Agrária no Brasil (org). São Paulo: Expressão Popular, 2005.

MEDEIROS, L.S, de. Lavradores, trabalhadores agrícolas, camponeses: Os comunistas e a constituição de classes no campo. Tese (Doutorado) - Programa de Pós-Graduação em Ciências Sociais, Universidade Estadual de Campinas, Campinas, 1995.

MOTTA, R.P.S. Em Guarda contra o perigo vermelho: O Anticomunismo no Brasil (19171964). Tese (Doutorado)- Programa de Pós-Graduação em História, Universidade de São Paulo, São Paulo, 2000

PRADO JR, C. A Questão Agrária no Brasil. Brasília: Editora Brasiliense, 1979. 
PRESTES, L.C. Manifesto de Agosto de 1950. In: VINHAS, M. O partidão: A luta por um partido de massas. São Paulo: Hucitec, 1982.

PRIORI, A. O PCB e a Questão Agrária: os manifestos e os debates políticos acerca de seus temas. In: MAZZEO, A.; LAGOA, M.I. Corações Vermelhos (org). Os comunistas brasileiros no século XX. 1. ed. São Paulo: Cortez, 2003, vol1, p.61-81.

RIDENTI, M. O Fantasma da Revolução Brasileira. São Paulo: Edunesp, 2010.

SANTOS, O. O Programa do Partido, a Questão Agrária, a organização e as lutas dos camponeses. Intervenção do IV Congresso do Partido Comunista Brasileiro. Novembro de 1954. Problemas. Revista Mensal de Cultura Política, nº64, dezembro de 1954 a fevereiro de 1955.

SILVA, A.da. O despertar do campo: Lutas camponesas no interior do Estado de São Paulo (1930-1945). São Paulo: Arquivo do Estado, Imprensa oficial, 2003.

SKIDMORE, T. Brasil: De Getúlio a Castelo (1930-1964). Rio de Janeiro: Paz e Terra, 1982. STOLCKE, V. Cafeicultura, homens, mulheres e capital (1850-1980). Brasília: Editora Brasiliense, 1986.

VINHAS, M. O partidão: A luta por um partido de massas. São Paulo: Hucitec, 1982. 